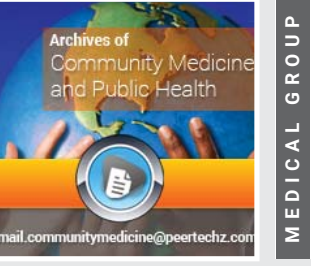

\title{
Pattern and predictors of sexual behaviour among adolescents in Ibadan, South West, Nigeria
}

\author{
Olorunsola $\mathrm{AM}^{1 *}$, Muyibi SA ${ }^{1}$, Irabor $\mathrm{AE}^{1}$, Adetunji $\mathrm{AA}^{1}$, \\ Ismail $\mathrm{WO}^{2}$ and Ogunniyan $\mathrm{T}^{3}$
}

'Department of Family Medicine, University College Hospital, Ibadan, Oyo State, Nigeria

${ }^{2}$ Department of Family Medicine, Obafemi Awolowo University Teaching Hospital, lle -Ife, Osun State, Nigeria

${ }^{3}$ Department of Community Medicine, University College Hospital, Ibadan Oyo State, Nigeria

Received: 31 July, 2021

Accepted: 16 August, 2021

Published: 17 August, 2021

*Corresponding author: Dr. Olorunsola AM, Consultant, Department of Family Medicine, University College Hospital, Ibadan, Oyo State, Nigeria, Tel: +2348030718626; E-mail: bimboolorunsola@gmail. com, bimoriji@yahoo.com

ORCID: https://orcid.org/0000-0002-0091-1512

Keywords: Pattern; Predictors; Sexual behavior; Adolescents; Nigeria

https://www.peertechzpublications.com

\section{Check for updates}

\section{Abstract}

Background: Adolescents are usually strong and known for vitality but reproductive and sexual issues constitute challenges to their health and well- being. Sexual choices are controlled by interaction of factors surrounding the adolescents' existence.

Aim: The study investigated the pattern and factors affecting sexual behaviour among adolescents in Ibadan, South West, Nigeria.

Method: A cross sectional study was conducted among sexually active adolescents at two Family Medicine Practice Clinics after obtaining ethical approval. Data was collected on sexual behaviour, socio demographic and family characteristics using interviewer administered questionnaire. Data was analysed with SPSS version 18 and test of association was done using chi-square and multiple logistic regression at $5 \%$ level of significance.

Results: The mean age of sexual debut was $18.82+2.804$ years, with age of onset being a year earlier among male respondents compared to females. Higher proportion of males (50.9\%) had intercourse before age 16 and were involved in sex with multiple partners (71.2\%). Females accounted more for inconsistent condom use (67.7\%) and transactional sex (73.3\%). Predictors of unsafe sexual behaviour were non- tertiary education (OR=2.05, Confidence Interval: $1.096-3.848)$, lower social class OR: 2.721, Confidence Interval: 1.422-5.308 and conflict- oriented family types (OR= 1.894 Confidence Interval: 1.036-3.462).

Conclusion: The findings showed different pattern of sexual behaviour among adolescents. Factors that predicted unsafe sexual practice were low education, poverty and family dysfunction. Ameliorating these factors will reduce risky sex pattern and related morbidities among adolescents' population.

\section{Introduction}

Health related behaviours among young people are influenced by factors in which they live, learn and grow up [1]. Sexual attitudes and practices among adolescents are influenced by interaction of both personal and proximal factors which include socio-cultural, family structures and functions where they grow [2-6].

Adolescents are at different developmental stages with those in early period struggling with self- identity while the older adolescents from age eighteen years seek for intimacy [7]. Desire for intimacy and its associated odds for sexual involvement increase with age of adolescents [8-11]. Early exposure to sexual activity is not without risk, particularly the younger aged adolescents 15 -19 years practised more harmful sex as regards inconsistent condom use compared to 20-24 years old adolescents [12].

Sexual behaviours also vary with the gender of adolescents, for instance the average age of sexual debut among males may be earlier than that of females $[8,13]$. Likewise proportion of sexually active males are more than females $[8,9]$. However young females are more likely not to use condom and engage transactional sex for gain than their male counterparts $[13,14]$.

The socioeconomic class of a young person influences sexual behaviour [14]. For instance, belonging to middle and low socioeconomic strata affect onset of sexual intercourse 
and use of condom $[10,15,16]$. Female adolescents from poor family background in attempt to meet basic needs involve in commercial sex for monetary gain [14]. Study showed that higher percentages of abortions and teenage mothers were accounted for by poor young females [17].

Religion as an institution that promotes morals and abstinence control sexual practices, religious Latino boys and girls were less likely to report premarital sex, relative to African American and non-Hispanic Whites [18]. Others studies also showed religion offered protection against risky sexual behaviour by delaying early sexual debut and promotion of condom use $[14,19,20]$.

Similarly, families where adolescents dwell and grow have been related to sexual choices $[21,22]$. Abstinence from sexual intercourse was associated with growing up in supportive families [23]. Good family functioning helps with safe sexual practice such as regular use of condom and maintaining relationship with steady partners among sexually active adolescents $[23,24]$. In contrast, poor parental support and prominent family conflicts lead to involvement in higher risky sexual behaviour with its resultant consequences [24,25]. This was evidenced in a comparison study where pregnant young females reported higher family conflict and less of cohesion than those not pregnant [24].

1.2 In addressing the reproductive health issues and in meeting the sustainable development goals' blueprint of reducing global health challenges which remained pervasive among young population in Nigeria, it is important to study the social and family characteristics contexts affecting sexual choices in this environment, thus the study assessed the pattern of sexual behaviour and its predictors among adolescents in Ibadan, Southwest, Nigeria.

\section{Materials and methods}

\section{Study setting and population}

A hospital based cross sectional study was carried out among sexually active adolescents between age 15-24 years, at two Family Medicine Clinics located at two Government Secondary Health Care that were selected from Government Secondary Hospitals in Ibadan Metropolis in Nigeria through computer based simple randomization.

\section{Study participants/process}

A total of 1480 respondents were screened for sexual activity using Adolescent Sexual Activity Index an 11 item scale [26]. Respondents with a score of 8 and above were considered sexually active out of which those that gave consents were recruited into the study using consecutive sampling until 370 sexually active respondents required as calculated from previous study [44] were enrolled.

Respondents were selected from each centre based on proportionate allocation from adolescents' record at each centre and the study lasted 4 months.

An interviewer administered-structured questionnaire was used to obtain data from sexually active respondents after obtaining informed consent while maintaining utmost privacy and confidentiality.

\section{Socio-demographic Characteristics}

Questions that answered objectives of the study were asked on bio-data such as age, level of education, family type and characteristics. Economic class was determined using Ogunlesi classification of social class for adolescents [27].

\section{Pattern of sexual behaviour}

Sexual behaviour assessment focused on age at first sexual intercourse, number of sexual partners over 12 months, consistency of condom uses and sex in exchange for money, gift or kind. Sexual behaviour was dichotomised into Safe and Unsafe. Risky sex was classified based on sexual debut on or before age 16 years, irregular condom use, transactional sex and multiple sexual partners. Respondents with absence of the aforementioned measures were classified as having safe sex.

\section{Family functioning}

Relationship within the family environment was assessed using Family Relationship Index (FRI) [6], a two-point scale which dichotomised quality of family interaction into Support Oriented and Conflict Oriented families after compilation of respondent raw scores on a standard scale.

\section{Data analysis}

Descriptive analysis of socio-demographic characteristics, pattern of sexual behaviour was done using measures like proportions, means. Pattern of sexual behaviour was further disaggregated by gender and was represented by a bar chart. Chi square was used to test association between sociodemographic, Family type and function with pattern of sexual behaviour. Multiple Logistic regression was used to test predictors of sex behaviour. Statistical level of significance was set at a $\mathrm{p}$ value of $\leq 0.05$.

\section{Ethical clearance}

The study was conducted after ethical clearance was obtained from the University of Ibadan/University College Hospital Institutional Ethical Committee (UI/EC/11/0083) and Oyo State Ethical Review (AD/13/479/256). Each study participant was recruited based on ethical principles for the guidance of physicians in medical research.

\section{Results}

\section{Sociodemography of respondents}

Table 1 shows the mean age of the respondents was $21.86 \pm 2.112$ years, majority $315(85.1 \%)$ of them were aged 20-24 years. Females accounted for a higher percentage $235(63.8 \%)$ with a mean of male to female ratio was $1 ; 1.8$ Highest proportion of the respondents $229(61.9 \%)$ had tertiary education and more $319(86.2 \%)$ belonged to Yoruba tribe. More of them 223 (60.3\%) practised Christian Religion and they were predominantly from monogamous family background 224 
(65.9\%). About half $186(50.3 \%)$ of the participants belonged to the lower social class.

\section{Pattern of sexual behaviour among respondents}

Table 2 below shows that overall mean age of sexual debut among the respondents was $18.82 \pm 2.804$ years. Fifty-nine $(15.9 \%)$ of the respondents had their first sexual intercourse before sixteen years while $311(84.1 \%)$ had sexual debut later Majority $235(63.5 \%)$ of the respondents failed to always use condom during intercourse. Less than one-fifth $15.9 \%$ had multiple sexual partners in the past 12 months and $45(12.2 \%)$ of the participants engaged in transactional sex.

\section{Pattern of sexual behaviour disaggregated by gender}

Assessment of sexual activity between male and female respondents shows the mean age of sexual debut was $18.31 \pm$ 2.707 years and $19.12 \pm 2.613$ years among males and females respectively. A higher proportion (50.9\%) of males had early first sexual intercourse compared to females $49.1 \%$. Females accounted more for inconsistent condom use $67.7 \%$ while males were $32.3 \%$. The male respondents accounted for a higher percentage $71.2 \%$ of adolescents with multiple sexual partners compared to females $28.8 \%$. More females $73.3 \%$ engaged in transactional sex than males $26.7 \%$ Figure 1.

Table 1: Socio- demographic Characteristics of Respondents $N=370$.

\begin{tabular}{|c|c|c|}
\hline Variable & Frequency (n) & Percentage (\%) \\
\hline \multicolumn{3}{|l|}{ Age } \\
\hline $15-19$ & 55 & 14.9 \\
\hline $20-24$ & 315 & 85.1 \\
\hline \multicolumn{3}{|l|}{ Sex } \\
\hline Male & 134 & 36.2 \\
\hline Female & 236 & 63.8 \\
\hline \multicolumn{3}{|l|}{ Level of education } \\
\hline Less than secondary school & 11 & 3.0 \\
\hline Secondary & 130 & 35.1 \\
\hline Tertiary & 229 & 61.9 \\
\hline \multicolumn{3}{|l|}{ Religion } \\
\hline Christianity & 223 & 60.3 \\
\hline Islam & 147 & 39.7 \\
\hline \multicolumn{3}{|l|}{ Ethnic group } \\
\hline Yoruba & 319 & 86.2 \\
\hline Igbo & 23 & 6.2 \\
\hline Hausa & 3 & 0.8 \\
\hline others & 25 & 6.8 \\
\hline \multicolumn{3}{|l|}{ Family of origin } \\
\hline Monogamous & 244 & 65.9 \\
\hline Polygamous & 126 & 34.1 \\
\hline \multicolumn{3}{|l|}{ Social class } \\
\hline Upper & 81 & 21.9 \\
\hline Middle & 103 & 27.8 \\
\hline Lower & 186 & 50.3 \\
\hline
\end{tabular}

Table 2: Pattern of Sexual Behaviour Among Respondents ( $N=370$ ).

\begin{tabular}{|c|c|c|}
\hline Variable & Frequency $(\mathbf{n})$ & Percentage $(\%)$ \\
\hline Age of sexual debut & & \\
\hline$<16$ years & 59 & 15.9 \\
\hline$\geq 16$ years & 311 & 84.1 \\
\hline Mean $18.82 \pm 2.804$ years & & \\
\hline Condom use during intercourse & \\
\hline Always & 135 & 36.5 \\
\hline Not Always & 235 & 63.5 \\
\hline Number of sexual partner & & \\
\hline Single & 311 & 84.1 \\
\hline Multiple & 59 & 15.9 \\
\hline Transactional Sex & & \\
\hline Yes & 45 & 12.2 \\
\hline No & 325 & 87.8 \\
\hline
\end{tabular}

\section{Assessment of socio -demograhic characteristics and sexual behaviour}

Table 3 shows that unsafe sexual behaviour among respondents aged $15-19$ years was $83.6 \%$ compared to $70.8 \%$ which was observed among respondents aged 20-24 years. This association was significant at a $\mathrm{p}$ value of 0.049 . A higher percentage of females $73.3 \%$ engaged in risky sexual behaviour but $71.5 \%$ males engaged in unsafe sex. However, this was not statistically significant. Social class and pattern of sexual behaviour had significant association, those from lowest social class accounted for most proportion of unsafe sex $83.3 \%$ compared to respondents from upper social class $53.3 \%$ at $\mathrm{p}<0.001$. Higher proportion of respondents with risky sexual behaviour had below tertiary education $(86.5 \%)$ while respondents with tertiary education accounted for $64.2 \%, \mathrm{p}=<0.001$. Also, a significant statistical difference was observed between respondents who were Muslims compared to Christians. $82.3 \%$ of Muslims practiced unsafe sex while 66.4 $\%$ of Christians accounted for same, $\mathrm{p}=0.001$. Also, a higher proportion of adolescents from polygamous families $(81.0 \%)$ accounted for risky sexual behaviour compared to those from monogamous family $(68.4 \%)$. The association was significant at $\mathrm{p}$ value $=0.01$.

\section{Influence of family functioning on sexual behaviour}

Table 4 shows there was a significant association between Family Functioning and sexual behaviour pattern. More proportion of respondents $231(75.2 \%)$ from conflict oriented family functioning engaged in unsafe sex behaviour compared to $38(60.3 \%)$ from support oriented family functioning type $\mathrm{p}=0.015$.

\section{Predictors of risky sexual behaviour}

Multiple logistic regression was carried out to test the independent effect of socio-demographic characteristics and family relationship index on pattern of sexual behaviour among the studied population. The findings indicated that the respondents who had less than tertiary education were 2.053 times more likely to engage in risky sexual behaviour 
than those with tertiary education $\mathrm{p}=0.025$. Respondents from lowest social class were about 3 times more likely to practice risky sexual behaviour than those from upper class, and this difference was significant at $\mathrm{p}$ value of 0.003 . Adolescents from conflict-oriented family functioning were 1.894 times more likely to practice risky sexual behaviour than those from support oriented-families $\mathrm{p}=0.038$. However, no statistical difference was observed in sexual behaviour between age, religion and family groups.

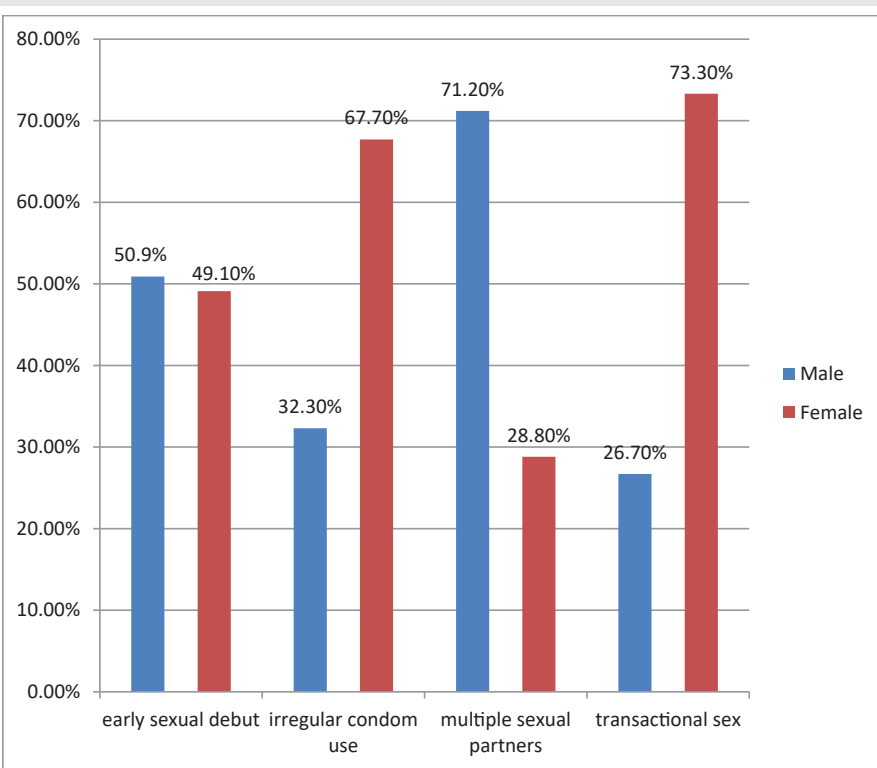

Figure 1: Differential Proportion of Sexual Behaviour Between Gender.

Table 3: Association between Socio-demographic Characteristics and Sexual Behaviour.

\begin{tabular}{|c|c|c|c|c|c|}
\hline Variable & Level & $\begin{array}{l}\text { Freq-Risky } \\
\text { behaviour }\end{array}$ & $\begin{array}{l}\text { Freq-Safe } \\
\text { behaviour }\end{array}$ & $x^{2}$ & $P$ value \\
\hline \multicolumn{6}{|l|}{ Age } \\
\hline & $15-19$ years & 46(83.6) & $9(16.4)$ & 3.891 & 0.049 \\
\hline & 20-24 years & 223(70.8) & $92(29.2)$ & & \\
\hline \multicolumn{6}{|l|}{ Sex } \\
\hline & Male & 96(71.6) & $38(28.4)$ & 0.119 & 0.730 \\
\hline & Female & 173(73.3) & $63(26.7)$ & & \\
\hline \multicolumn{6}{|c|}{ Level of Education } \\
\hline & Non tertiary & $122(86.5)$ & 19(13.5) & 21.931 & $<0.001$ \\
\hline & Tertiary & $147(64.2)$ & $82(35.8)$ & & \\
\hline \multicolumn{6}{|c|}{ Family Structure } \\
\hline & Monogamous & $167(68.4)$ & $77(31.6)$ & 6.552 & 0.010 \\
\hline & Polygamous & 102(81.0) & $24(19.0)$ & & \\
\hline \multicolumn{6}{|l|}{ Religion } \\
\hline & Christianity & 148(66.4) & $75(33.6)$ & 11.350 & 0.001 \\
\hline & Islam & $121(82.3)$ & $26(17.7)$ & & \\
\hline \multicolumn{6}{|c|}{ Social Class } \\
\hline & Lower & 155(83.3) & $31(16.7)$ & 27.035 & $<0.001$ \\
\hline & Middle & 71(68.9) & $32(31.1)$ & & \\
\hline & Upper & $43(53.1)$ & $38(46.9)$ & & \\
\hline
\end{tabular}

Table 4: Association between Quality of Family Relationship Index and Pattern of Sexual Behaviour.

\begin{tabular}{|c|c|c|c|c|c|}
\hline Variable & Level & $\begin{array}{c}\text { Freq-Risky } \\
\text { Behaviour }\end{array}$ & $\begin{array}{c}\text { Freq-Safe } \\
\text { Behaviour }\end{array}$ & X2 & P-value \\
\hline $\begin{array}{c}\text { Family- } \\
\text { Relationship } \\
\text { Index }\end{array}$ & Support-Oriented & $38(60.3)$ & $25(39.7)$ & 5.869 & 0.015 \\
\hline & Conflict-Oriented & $231(75.2)$ & $76(24.8)$ & & \\
\hline & & & & \\
\hline
\end{tabular}

Table 5: Logistic Regression of Factors associated with Risky Sexual Behaviour.

\begin{tabular}{|c|c|c|c|}
\hline Variable & Odds Ratio & 95\% C.I. & p-value \\
\hline \multicolumn{4}{|l|}{ Age } \\
\hline $15-19$ years & 1.480 & $0.660-3.316$ & 0.341 \\
\hline 20-24 years & 1 & & \\
\hline \multicolumn{4}{|l|}{ Level of Education } \\
\hline Non tertiary & 2.053 & $1.096-3.848$ & $0.025^{\star}$ \\
\hline Tertiary & 1 & & \\
\hline \multicolumn{4}{|l|}{ Family of Origin } \\
\hline Monogamous & 1 & & \\
\hline Polygamous & 1.184 & $0.665-2.111$ & 0.566 \\
\hline \multicolumn{4}{|l|}{ Social Class } \\
\hline Lower & 2.721 & $1.422-5.208$ & $0.003^{*}$ \\
\hline Middle & 1.682 & $0.900-3.144$ & 0.103 \\
\hline Upper & 1 & & \\
\hline \multicolumn{4}{|l|}{ FRI } \\
\hline Support Oriented & 1 & & \\
\hline Conflict Oriented & 1.894 & $1.036-3.462$ & $0.038^{*}$ \\
\hline \multicolumn{4}{|l|}{ Religion } \\
\hline Christianity & 1 & & \\
\hline Islam & 1.440 & $0.816-2.541$ & 0.209 \\
\hline
\end{tabular}

The variable for reference is the one with odds ratio of 1

\section{Discussion}

The mean age of sexual debut was 18.82 years in this study, this was close to the mean age recorded in the National Demographic Health Survey [28] and also with the work by Annete, et al. [29] in Uganda which was 18 years, but was much higher than the mean age of 15.4 years reported among American Adolescent Nationals by Aspy, et al. [30]. The observed difference could be attributed to cultural variation between developed and developing countries. The former society compared to the latter allows for early independence which can lead to premature decision making with regards to sexual activity.

Disparity was observed in the age of first sexual intercourse between male and female as was documented in few studies $[20,31]$. For instance, sexual debut was a year lower among male respondents compared to females. Also, use of condom was poor in this study just as it has been found by other studies [32-35]. Further analysis on the effects of socio-demographic factors, showed that females accounted for a higher proportion of irregular condom use, consistent with findings of both Wouhabe [35] in Ethiopia and Olasode in Nigeria [36]. Gender 
norms of male dominance during sexual activity and on decision for condom must have played a role. Another reason for low condom use among females in this study could be attributed to their involvement in transactional sex for money, gift or other gains which would reduce their ability to negotiate for protection during intercourse. Aforementioned observation buttressed the fact that unprotected sexual intercourse is preponderance as a cause of worsening reproductive health indices among young population in Nigeria.

Masculinity had influence on number of sexual partners, male respondents accounted for more involvement with multiple partners than females.

Role of age was observed as higher proportion of sexually active adolescents were seen after fifteen years of age confirming previous reports that sexual practice increases with age [9,32]. Although, younger adolescents had tendency to practice unsafe sex more than older adolescents in this study and this was in keeping with other studies [38,39]. Early aged adolescents are less likely to make informed decision and are more likely to involve in coercive sex and other associated risks. Early initiators have been shown to lack the ability to negotiate condom use during sexual intercourse [37,40] and have likelihood for multiple sexual partners from serial relationships before marriage $[37,39]$.

Religion is an entity with values that protect against risky sexual behaviour [3,11,20,29], youths who practiced Christianity in this study had reduced engagement in risky sexual activity. Although, Isiugo, et al. observed that religion type had no effect on risky sex behaviour in a National survey [42].

Education as a factor showed that respondents with tertiary education were less involved in unsafe sexual behaviour, similar to other report that education confers an advantage on pattern of sexual activity [16].

Furthermore, the study revealed the importance of family characteristics on pattern of sex behaviour. Polygamy being embedded in conflict from partner rivalry accounted for higher proportion of youths with risky sexual behaviour [11,41,43,44]. Negative impact leads to pressure exposure from peers and eventual unsafe sexual practice $[23,44,45]$. Likewise, the quality of family functioning showed that adolescents from support oriented families were less likely to practice risky sex compared to ones from conflict families. Good family functioning improves bond and communication among family members, an interaction which promotes secured atmosphere to address age related health behaviour such as safe sex $[6,18,22,24]$

Lastly, poor economy in family was associated with the highest percentage of risky sex as found in some studies $[16,14,42]$. Poverty has been strongly linked with low education, inadequate information on condom use and likelihood of transactional sex for monetary gains [15,32]. Consistent effect of poverty and low education in predicting pattern of sexual practice emphasise their roles in unsafe sexual practice and sex related morbidities and mortalities in low income countries as Nigeria.

\section{Conclusion}

The findings showed that the pattern of sexual behaviour among adolescents were at variance of safe and unsafe sexual practice. The paradox observed with high inconsistent use of condoms in this study despite advancement in promoting contraception among young population globally showed a persistent gap in the health of adolescents and young people in Nigeria and Africa at large. Knowing that low level of education, poverty and poor family functioning were identified as predictors of unsafe sexual behaviour in this study. Strategies to improve on education and household finances should be effected in order to promote awareness and adoption of safe sexual practice among young population in this environment. Lastly comprehensive approach to adolescent care must explore family functioning in planning intervention for healthy social integration and safe sexual practice.

In addition, parents should seek help in dealing with family conflicts in order to provide home front that favour healthy sex behaviour. All stakeholders are keys to preventing risky sexual practice and its attendant health burden among young population.

\section{Limitation}

The cross- sectional nature of this study limits its ability to establish causal relationship between pattern of sexual activity and identified influencing factors.

\section{Acknowledgement}

Profound gratitude to W.B. Hansen for providing access to the full version of Adolescent Sexuality Scale (ASAI).

\section{References}

1. Braveman P, Gottlieb $L$ (2014) The Social Determinants of Health: It's time to consider the causes of the causes. Public Health Rep 129: 19-31. Link: https://bit.ly/3iSaSQh

2. Asamoah BO, Agardh A (2017) Individual and Family Level Determinants of Risky Sexual Behaviours Among Swedish and Foreign Young Adults 18-30 years of Age, Residing in Skane,Sweden. Arch Sex Behav 47: 517-528. Link: https://bit.ly/3snpjyM

3. Fatusi AO, Blum W (2008) Predictors of early sexual initiation among nationally representative sample of Nigerian Adolescents. BMC Public Health 8: 136. Link: https://bit.ly/3snEHLC

4. World Health Organization (2012) Defining sexual health Report of a technical consultation on sexual health 2002. WHO Geneva. 2006

5. Bray JH, Campbell TL (2007) The family influence on health. In: Saunders E. Rakel textbook of family Medicine. $7^{\text {th }}$ Edition An Imprint of Elsevier 14-17. Link: https://bit.ly/37Re6wV

6. Moos H (2009) Family Environment Scale. Family Environment Scale Manual and Sampler Set: Development, Applications and Research: 4TH edition 31-34 Link: https://bit.ly/37OBMSJ

7. Erikson E (2012) In: Harder AF. Childhood and Society by Erik the Developmental Stages of Erik Erikson.

8. Egbochuku EO, Ekanem IB (2008) Attitude of Nigerian secondary school adolescent toward sexual practices: implications for counselling 
practices. European Journal of Scientific Research 22: 177-183. Link: https://bit.ly/3CWkAsH

9. Yeboa E, Eneanor M (2008) Factors influencing timing of first sexual intercourse in young people in Kenya. Int Fam Plan Perspect 34: 177-188. Link: https://bit.ly/3xWmrtQ

10. Ishida K, Stupp P, McDonald O (2011) Prevalence and correlates of sexual risk behaviours among Jamaican adolescents. Int Perspect Sex Reprod Health 37: 6-15. Link: https://bit.ly/3AKst2H

11. Slap G, Lucy L, Huang B, Comfort A, Zink TM, et al. (2003) Sexual behaviour of adolescents in Nigeria: cross sectional survey of secondary school students. BMJ 326: 15. Link: https://bit.ly/3m8Trgd

12. Stephenson R (2009) Community influences on young people's sexual behaviour in 3 African countries. Am J Public Health 99: 102-109. Link: https://bit.ly/3k60tya

13. Odu BK, Akanle FF (2008) Knowledge of HIV/AIDS and sexual behaviour among the youths in south west Nigeria. Humanity \& Social Sciences Journal 3: 81-8. Link: https://bit.ly/2Xtyhz7

14. Thabo TF (2010) The connection between poverty, sexual activity, knowledge about HIV/AIDS and willingness to test for HIV infection among young people European Journal of Sciences 15: 115-128. Link: https://bit.ly/3gbTynt

15. Dinkelman T, Lam D, Leinbranddt M (2007) Household and community income, economic shocks and risky sexual behaviour of young adults. AIDS 21: S49-S56. Link: https://bit.ly/3sIQkCE

16. Isiugo-Abanihe UC, Oyediran KA (2004) Household socioeconomic status and sexual behaviour among Nigerian female Youth. African Population Studies 19: 81-98. Link: https://bit.ly/3yWwTmt

17. Klein JD (2001) Adolescent pregnancy- current trends and issues. Journal of American Paediatrics Academy 116: 281-285.

18. Stauss K, Murphy-ErbyJavier Y, Bivens BV (2011) Parent-child communication related to sexual health: the contextual experiences of rural Latino parents and youth. Advances in Social Work 12: 181-200. Link: https://bit.ly/3D4151E

19. AghaS, Hutchinson $P$, Kusanthan $T$ (2006) The effects of religious affiliation on sexual initiation and condom use in Zambia. J Adolesc Health 38: 550-255. Link: https://bit.ly/3iPdyhA

20. Odimegwu CO, Solanke LB, Adedokun A (2002) Parental characteristics and adolescent sexual behaviour in Bida local government Area of Niger State, Nigeria. Afr J Reprod Health 6: 95-106. Link: https://bit.ly/3g8naCn

21. Adejumo GO (2011) Impact of family type on involvement of adolescents in premarital sex. International Journal of Psychology and Counselling 3: 15-19. Link: https://bit.ly/3APynzo

22. Kirby D (2007) In: O’Donnell L, Rene'e W, Kim D, Varzi J, Mynth A, Jesse M, et al Saving Sex for Later: developing apparent child communication intervention to delay sexual initiation among young adolescents. Journal of Sex Education 7: 107-125.

23. Pamela J, Jennifer K (2002) Predictors of risky sexual behaviour in African American adolescent girls: implications for prevention interventions. J Pediatr Psychol 27: 519-530. Link: https://bit.ly/37OBUBH

24. Lagina N (2002) Parent-child communication promoting sexually healthy youth. Link: https://bit.ly/3m3Xaf8

25. Caal SN (2008) Adolescent sexual development: Contextualizing a cognitive process in the decision to engage in protective or risky sexual behaviour ProQuest Dissertation \& Theses 252: 3305907. Link: https://bit.ly/3k03hOR

26. Hassen WB, Paskett ED, Carter LJ (1999) The adolescent sexual activity index a Standardizes strategy for measuring interpersonal heterosexual behaviours among youths. Oxford Journals 14: 485-490. Link: https://bit.ly/370CKOT
27. Oyelesi IN, Ogunlesi TA, Dedeke IOF, Kuponiyi OT (2000) Socio-economic classification of children attending specialist paediatric centres,Ogun state. Nig Med Practi 54: 21-25.

28. National Population Commission (2004) Nigeria Demography and Health Survey 2003. Link: https://www.dhsprogram.com/pubs/pdf/FR148/FR148. pdf

29. Anette AM, Tumwine G, Östergren P (2011) The Impact of socio-demographic and religious factors upon sexual behaviour among Ugandan university students. Plos One 6: e23670. Link: https://bit.ly/2XnljTt

30. Aspy CB, Vesley SK, Oman RF, Rodine S, Marshall L, et al. (2007) Parenta communication and youth sexual behaviour. J Adolesc 30: 449-466. Link: https://bit.ly/3xTdBNq

31. O'Donnell BL, O'Donnell CR, Stueve A (2001) Early sexual initiation and subsequent sex-related risks among urban minority youth: reach for health study. Fam Plan Perspect 33: 268-275. Link: https://bit.ly/3k03Lo9

32. Imaledo JA, Peter-Kio OB, Asuquo EO (2012) Patten of risky sexual behaviour and associated among undergraduate students of the University of Port Harcourt, Rivers State, Nigeria. Pan Afr Med J 12: 97. Link: https://bit.ly/370ahbR

33. Urassa W, Moshiro C, Chalamilla G, Mhalu F, Sandstrom E (2008) Risky sexual practices among youth attending a sexually transmitted infection clinic in Dares Salaam, Tanzania. BMC Infect Dis 8: 159. Link: https://bit.ly/3g91966

34. Aderibigbe SA, Araoye MO (2011) Teenage pregnancy and prevalence of abortion among in-school adolescents in north central, Nigeria. Asian Soc Science 7: 122-127. Link: https://bit.ly/3xRkkrh

35. Person J, Muller C, Kathleen M, Debra M (2005) Parenting influences on early sex initiation among adolescents parental involvement, family structure, \& adolescent sexual decision making. Journal of Family Issues 26: 32-54

36. Olasode OA (2007) Sexual behaviour in adolescent and young people attending sexually transmitted clinic in Ile Ife. Indian Journal of STD and AIDS 28: 83-86. Link: https://bit.ly/2VVbCLo

37. Ntaganira J, Hass LJ, Hosner S, Brown L, Moc NB (2012) Sexual risk behaviours among youth heads of household in Gikongoro, south province of Rwanda. BMC Public Health 12: 225. Link: https://bit.ly/2XyrleN

38. Ajuwon AJ, Olaleye A, Faromoju B, Oladapo O (2006) Sexual behavio and experience of sexual coercion among secondary school students in three states in North Eastern Nigeria. BMC Public Health 6: 310. Link: https://bit.ly/3iSf2Yv

39. Dongurum CK, Marcus ND (2009) Sex behaviour of adolescents in Qua'anpan local government area, Plateau State. Nig J of Soc Reseac 1: 80-92. Link: https://bit.ly/3m6KNyL

40. Bamidele JO, Abodunrin OL, Adebimpe WO (2009) Sexual behaviou and risk of HIV/AIDS among adolescents in public secondary schools in Osogbo, Osun State, Nigeria. Int J Adolesc Med Health 21: 387-394. Link: https://bit.ly/3iPkzyK

41. Markham CM, Lormand D, Gloppen KM, Peskin MF, Flores B, et al. (2010) Connectednes as a predictor of sexual and reproductive health outcomes for youth. J Adolesc Health 46: S23-S41. Link: https://bit.ly/3sql59v

42. Isiugo- Abanihe UC, Oyediran KA (2004) Household socioeconomic status and sexual behaviour among female youth. Afr Pop Studies 19: 81-98. Link: https://bit.ly/3ANd8yb

43. Mmbaga EJ, Leonard F, Leyn GH (2012) Incidence and Predictors of Adolescent's Early Sexual Debut after Three Decades of HIV Interventions in Tanzania: A Time to Debut Analysis. Plos One 7: e41700. Link: https://bit.ly/37ReoE1

Citation: Olorunsola AM, Muyibi SA, Irabor AE, Adetunji AA, Ismail WO, et al. (2021) Pattern and predictors of sexual behaviour among adolescents in Ibadan, South West, Nigeria. Arch Community Med Public Health 7(2): 175-181. DOI: https://dx.doi.org/10.17352/2455-5479.000158 
44. Amoran OE, Onadeko MO, Adeniyi JD (2004) Parental influence on adolescent sexual initiation in Ibadan. International Quarterly of Community Health Education 23: 73-81. Link: https://bit.ly/3ySVBUT
45. Okonkwo PI, Fatusi AO, llika AL (2005) Perception of peers' behaviour regarding sexual health decision making among female undergraduates in Anambra State, Nigeria. Afr Health Sci 5: 107-113. Link: https://bit.ly/3k2dytL
Discover a bigger Impact and Visibility of your article publication with

\section{Peertechz Publications}

\section{Highlights}

* Signatory publisher of ORCID

* Signatory Publisher of DORA (San Francisco Declaration on Research Assessment)

* Articles archived in worlds' renowned service providers such as Portico, CNKI, AGRIS, TDNet, Base (Bielefeld University Library), CrossRef, Scilit, J-Gate etc.

* Journals indexed in ICMJE, SHERPA/ROMEO, Google Scholar etc.

* OAI-PMH (Open Archives Initiative Protocol for Metadata Harvesting)

* Dedicated Editorial Board for every journal

* Accurate and rapid peer-review process

* Increased citations of published articles through promotions

* Reduced timeline for article publication

Submit your articles and experience a new surge in publication services (https://www.peertechz.com/submission).

Peertechz journals wishes everlasting success in your every endeavours.

Copyright: @ 2021 Olorunsola AM, et al. This is an open-access article distributed under the terms of the Creative Commons Attribution License, which permits unrestricted use, distribution, and reproduction in any medium, provided the original author and source are credited. 